\title{
MANGROVE MONITORING USING NORMALIZED DIFFERENCE VEGETATION INDEX (NDVI): CASE STUDY IN NORTH HALMAHERA, INDONESIA
}

\section{MONITORING MANGROVE MENGGUNAKAN MODEL NORMALIZED DIFFERENCE VEGETATION INDEX (NDVI): STUDI KASUS DI HALMAHERA UTARA, INDONESIA}

\author{
Yerik Afrianto Singgalen $^{1 *}$, Candra Gudiato ${ }^{2}$, Sri Yulianto Joko Prasetyo ${ }^{3}$, \& Charitas Fibriani $^{3}$ \\ ${ }^{1 *}$ Tourism Department, Faculty of Administration Business and Communicaiton Science, Atma Jaya \\ Catholic University of Indonesia, South of Jakarta, 12930, Indonesia \\ ${ }^{2 \& 3}$ Master Program in Information Systems, Faculty of Information Technology, Satya Wacana \\ Christian University of Indonesia, Salatiga, 50711, Indonesia \\ *E-mail: yerik.afrianto@atmajaya.ac.id
}

\begin{abstract}
Community-based ecotourism is an appropriate approach which is effectively preserved mangrove sustainability. As an effort to identify the priority areas of mangrove development, mangrove density levels need to be analyzed. The distribution of mangroves with the lowest average density value needs to be prioritized as a preservation and conservation strategy through community-based ecotourism concept. This article aims to identify the distribution of mangroves using the normalized difference vegetation index (NDVI) model in North Halmahera Regency, Indonesia. Also, discuss the sustainable livelihoods' perspective. This study adopted a mixed-method. Data processing is divided into two stages: first stage, mapping the distribution of mangroves based on density levels; second stage, triangulation. Landsat 8 operational land imager (OLI) in 2013 and 2021 were used as primary data to get the NDVI value, and categorized mangrove density level in Pilawang Cape, Kumo Island, Kakara Island, Maiti Island, and Tagalaya Island. The findings show that Pilawang Cape has the lowest NDVI value. The average NDVI value in 2021 is 0.22 which can be categorized as a rare mangrove forest according to the mangrove standard damage criteria. Thus, Mangrove area in Pilawang Cape needs to be prioritized as a preservation and conservation strategy through community-based ecotourism concept.
\end{abstract}

Keywords: ecotourism, livelihood, mangrove, NDVI

\begin{abstract}
ABSTRAK
Ekowisata berbasis masyarakat menjadi salah satu pendekatan yang efektif dalam menjaga kelestarian hutan mangrove. Strategi untuk menetapkan prioritas pengembangan kawasan mangrove, dapat dilakukan dengan menganalisis kerapatan hutan mangrove. Kawasan mangrove dengan nilai kerapatan paling rendah perlu diprioritaskan sebagai strategi preservasi dan konservasi melalui konsep ekowisata berbasis masyarakat. Artikel ini bertujuan mengidentifikasi sebaran mangrove menggunakan model normalized difference vegetation index (NDVI) di Kabupaten Halmahera Utara, Indonesia. Perspektif penghidupan berkelanjutan digunakan untuk mendiskusikan konteks sosiokultural masyarakat lokal. Penelitian ini mengadopsi metode campuran. Pengolahan data terbagi menjadi dua tahap yakni: tahap pertama, pemetaan sebaran hutan mangrove berdasarkan tingkat kerapatan; tahap kedua, trianggulasi. Pemetaan sebaran hutan mangrove menggunakan citra satelit Landsat 8 operational land imager (OLI) tahun 2013 dan 2021 serta model NDVI di Tanjung Pilawang, Pulau Kumo, Pulau Kakara, Pulau Maiti, dan Pulau Tagalaya. Hasil penelitian ini menunjukkan bahwa Tanjung Pilawang pada zona 1 dan 2 memiliki Nilai NDVI paling rendah di tahun 2021 yakni 0,22 dengan kategori jarang, sehingga perlu diprioritaskan dalam pengembangan ekowisata mangrove berbasis komunitas sebagai strategi perlindungan kawasan hutan mangrove.
\end{abstract}

Kata kunci: ekowisata, mangrove, NDVI, penghidupan 


\section{INTRODUCTION}

Mangrove is a natural capital that supports the livelihoods of coastal communities. Li et al. (2016) argue that mangrove forests play an important role in subtropical and tropical coastal ecosystems that support endophytic fungal ecosystems. Endophytic fungi have benefits in increasing plant resistance to disease. Furthermore, Joel \& Bhimba (2013) show that the Meyerozyma guilliermondii fungus grows in mangrove areas and has benefits as an anti-cancer drug. On the other hand, Analuddin et al. (2019) argue that mangrove fruits are known as Xylocarpus granatum, Sonneratia alba, and Bruguiera gymnorrhiza have high protein content. This shows that mangroves have benefits for the development of health products. In addition, mangroves can protect coastal community settlements from large waves at risk of causing abrasion (Marois \& Mitsch, 2015). Thus, mangrove can be developed to become products of economic value for the sustainability of coastal communities' livelihoods.

The livelihoods of coastal communities rely on mangroves as an ecological-based tourist attraction known as the eco-tourism. Mangroves are very beneficial for the livelihoods of coastal communities. Therefore, the condition of mangrove forests needs to be protected and monitored from time to time. Yotsumoto (2012) stated that eco-tourism is an environmentally friendly concept with economic and social values to support communities' livelihoods around tourism destinations. Cheung \& Jim (2013) stated that eco-tourism can be sustainable if managed optimally by taking into account the typology of visitors (eco-tourist) based on the purpose of visiting, namely, knowledge seekers leisure travelers, and nature lovers. This shows that in addition to optimal destination management, visiting tourists' characteristics will affect the sustainability of eco-tourism. Li et al. (2020) stated that tourists' experiences and perceptions influence the eco-tourism sustainability. Specifically, tourists' education, experiences, and values also influence attitudes and actions towards the natural and social environment (Chai-Arayalert, 2020). Thus, the ideal eco-tourism concept represents various stakeholders that balances the environmental, socio-cultural, economic and political dimensions. On the other hand, each mangrove area shows different problems. Therefore, research on mangrove areas needs to be carried out intensively based on each context.

The distribution of mangroves in coastal and island areas needs to be identified, classified, analyzed based on density level. It is necessary to control mangrove conditions from fatal damage. One model that can be used for mangrove monitoring is normalized difference vegetation index (NDVI) model. Several previous researchers adopted the NDVI model with other models to make land-use maps. For example, Guha et al. (2018) used Landsat 8 oil satellite imagery and the NDVI model and the normalized difference built-up index (NDBI) to identify land use and classify differences in land use and buildings. Wei et al. (2020) also adopted NDVI and LAI to evaluate biomass in reforestation sites based on area. The NDVI model was adopted to identify land use or vegetation areas on the surface (Arjasakusuma, 2018; Glenn \& Tabb, 2019; Tao et al., 2019; Verbyla \& Kurkowski, 2019). Meanwhile, the LAI model is used to identify leaf density based on plant characteristics on the surface (Carrasco-Benavides et al., 2016; Kganyago et al., 2020; Wicaksono \& Hafizt, 2013; Zhu \& Zeng, 2016). Thus, NDVI can be used to identify the distribution and density percentage of mangroves in coastal areas and islands.

Previous studies have shown the use of Landsat satellite imagery for remote sensing. Remote sensing is one strategy for monitoring the earth's surface remotely using 
satellites. Remote sensing can be used as a visualization of the real conditions in coastal areas and islands. Islam et al. (2019) used Landsat satellite imagery of MMS, TM, $\mathrm{ETM}+$ and L8 OLI to identify the distribution of mangroves using the dark object subtraction (DOS) and relative radiometric normalization (RRN) models based on pseudo-invariant features (PIFs). Based on the classification results, land classification is based on phenomena and activities such as deforestation, shrimp and salt cultivation, erosion and sedimentation, and mangrove planting with accuracy levels of Landsat MMS satellite imagery (80\%), TM (80\%), ETM + (87 \%), and L8 OLI (97\%). This shows that the use of satellite imagery can be used to classify land use in an area. Datta \& Deb (2012) show that coastal areas need to be analyzed using remote sensing to identify land use and changes caused by the tourism sector's growth, agricultural activities, and settlements. Remote sensing using satellite imagery can be used based on models and research objectives (Kushnir et al., 2010; Mo et al., 2015; Qiu et al., 2014; Zhai et al., 2015).

Mangroves are essential natural resources in maintaining the sustainability of community-based ecotourism in coastal and island areas. Therefore, it needs to be managed optimally to maintain authentic environmental conditions (Bulmer et al., 2017). Several previous researchers have shown that people's livelihoods in coastal areas can be sustainable if there are mobility and accessibility to resources (Singgalen, 2020). The identified resources are human capital, physical capital, financial capital, social capital, and natural capital (Singgalen et al., 2019c). The livelihood context of coastal communities will show differences in coping and survival strategies because they are dominated by local culture's structure and values (Singgalen \& Simange, 2018). The coping and survival strategy has led to diversification, intensification, extensification, and transformation of livelihood (Singgalen et al., 2017; Singgalen et al., 2018; Singgalen et al., 2019a, 2019b, 2019d).

Studies on mangrove forests, ecotourism, and coastal community livelihoods need to be analyzed based on remote sensing results to classify the mangrove vegetation index in each study area. Thus, mobility and accessibility to resources and a sustainable livelihood framework focus on describing coping and survival strategies and prioritizing the protection of mangrove areas with rare category vegetation index values. In the context of this research, we will discuss the livelihoods of coastal and island communities since the development of the regional tourism sector through the concept of community-based ecotourism development. Specifically, this research's location is located in Tagalaya Island, Kakara Island, Maiti Island, Kumo Island, and Pilawang Cape, North Halmahera Regency, North Maluku Province Indonesia. Meanwhile, the theoretical perspective used is the sustainable livelihood concept framework adopted by Department for international development (DFID). Thus, this study's results can be developed as recommendations for mangrove protection through ecotourism for sustainable mobility of local community livelihoods.

\section{RESEARCH METHODS}

\subsection{Time and Place of Research}

This research was conducted from August to December 2020 in Kakara Island, Maiti Island, Tagalaya Island, Kumo Island and Pilawang Cape, North Halmahera Regency, North Maluku Province, Indonesia (Figure 1).

The research method used is a mixedmethod to describe coping strategies and survival strategies for coastal and island communities by using resources as supporting sustainable livelihoods. Resources in sustainable livelihoods are assets or capital as follows: natural capital, physical capital, 


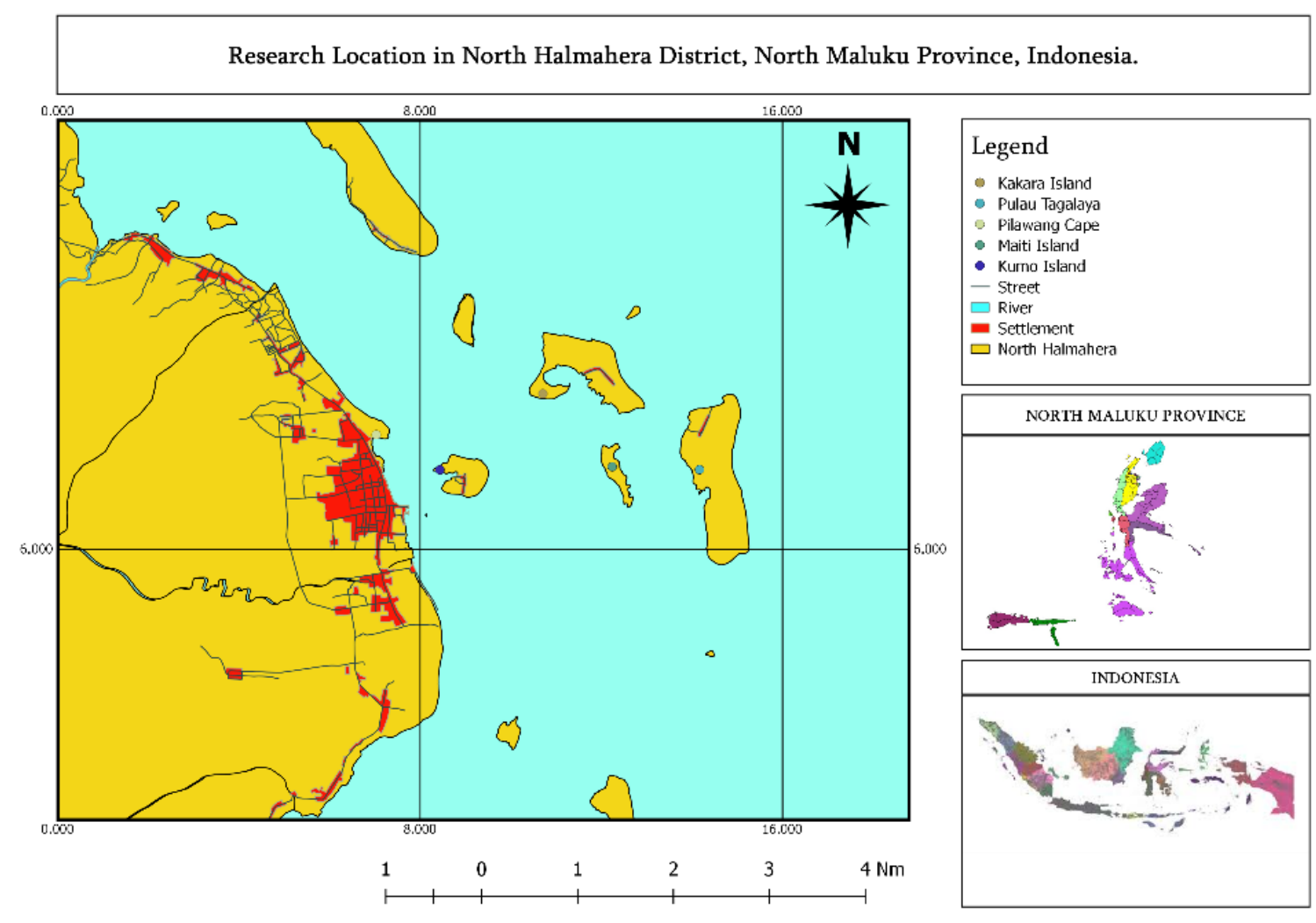

Figure 1. Research location. (Source: Digitized by QGIS).

financial capital, social capital and human capital. In the context of this research, natural resources or capital are limited to the availability of mangroves in coastal areas that local communities can access. Meanwhile, the physical capital referred to is the availability of facilities and infrastructure to support ecotourism activities at the research location. Human capital refers to knowledge and skills related to efforts to optimize mangrove areas' managerial aspects through the concept of sustainable ecotourism. Also, the social capital referred to in this research is cultural-based collective values embodied in the form of local wisdom of local communities to optimize mangrove resources that have economic value and support sustainable livelihoods.

Meanwhile, the financial capital that is meant is mobility and accessibility to operational budgets and mangrove areas' development as an ecotourism attraction, which is supported institutionally through regional tourism development policies. The data collection process using in-depth interview techniques, observation, and document study. In-depth interviews were conducted with key informants related to the local community's socio-cultural aspects, especially local wisdom related to the use of mangrove area resources as a support for sustainable livelihoods. Observations conduct to identify mangrove conditions at the research location. This research also uses survey and remote sensing methods. Research instruments such as the Phantom 4 version 2 drone used to record the mangrove forest in the research location. Satellite imagery of Lansat 8 OLI 2020 was used to classify maps of mangrove distribution and land use by local communities using the normalized model difference vegetation index (NDVI). Meanwhile, the Central Statistics Agency document study was conducted to obtain data on the study area. The data processing is divided into two stages: first, identification of the distribution of mangrove ecosystems using the NDVI 
model; second, triangulation of the results of in-depth interviews, observation and document study.

\subsection{Material and Data: Normalized Difference Vegetation (NDVI)}

In the first stage, the transverse mercator (UTM) on Landsat 8 operational land imager (OLI) satellite imagery data is set based on the 1984 world geodetic system (WGS) datum. Ground control points (GCP) are selected based on the research location (Figure 2).

Furthermore, in the data processing preparation stage, a classification based on RGB 6-5-3 is carried out to sort out mangrove vegetation from dark green and light green land vegetation. This study uses the NDVI model to identify the mangrove vegetation index (Bhavsari et al., 2017). Thus, the distribution and standard criteria for mangrove damage can be seen as stated in the Decree of the Minister of Environment Number 201 of 2004 in Table 1.

Table 1 is the standard criteria for mangrove environmental damage indicators that can be used as a benchmark for analyzing the condition of mangrove resources for the benefit of ecotourism development. Based on the classification using the NDVI model, it can be seen that the standard criteria for mangrove damage in each research location as a consideration in making decisions to determine community-

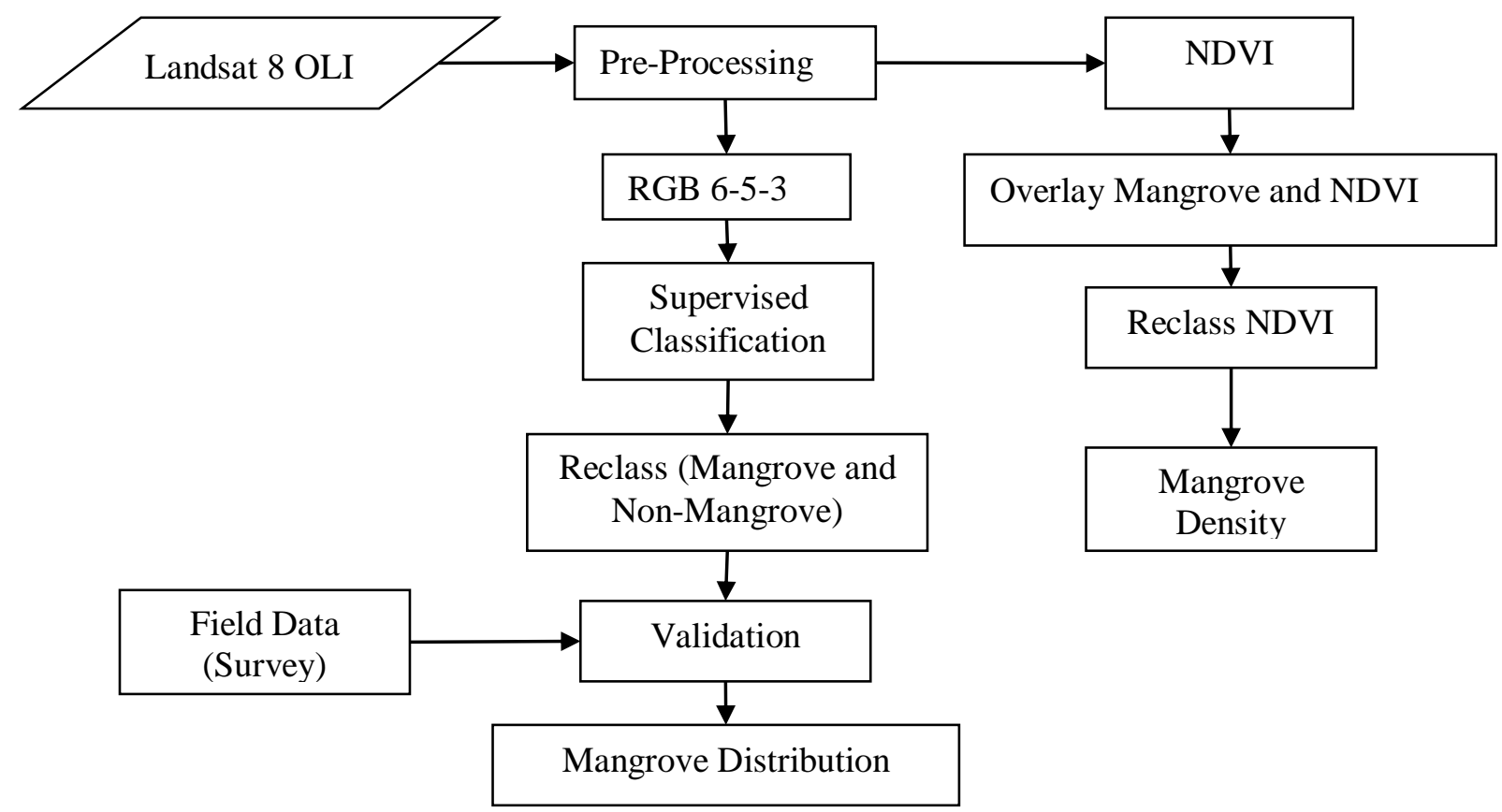

Figure 2. Data Processing Using Normalized Difference Vegetation (NDVI).

Tabel 1. Mangrove damage standard criteria.

\begin{tabular}{cllll}
\hline & Criteria & \multicolumn{1}{c}{ C } & \multicolumn{1}{c}{ D } & NDVI \\
\hline Good & Dense & $\geq 75 \%$ & $>1500$ & $0,43 \leq$ NDVI $\leq 1,00$ \\
& Moderate & $\geq 50-<75$ & $\geq 1000-<1500$ & $0,33 \leq$ NDVI $\leq 0,42$ \\
Broken & Rare & $<50$ & $<1000$ & $-1,0 \leq$ NDVI $\leq 0,32$ \\
\hline Notes: C & Cover $(\%)$, D=Density(Tree/ha), NDVI-Normalized Difference Vegetation Index
\end{tabular}

Notes: $\mathrm{C}=$ Cover (\%), D=Density(Tree/ha), NDVI=Normalized Difference Vegetation Index. Source: ( Ministry of Environment and Forestry, 2004). 
Tabel 2. NDVI value in Tagalaya, Maiti, Kakara, Kumo and Pilawang Cape.

\begin{tabular}{llllll}
\hline Location & Zone 1 $(\mathrm{A})$ & Zone 2(A) & Zone 3(A) & Zone 4(A) & MA \\
\hline Tagalaya & 0.33 & 0.46 & 0.49 & 0.16 & 1.44 \\
Maiti & 0.06 & 0.08 & 0.05 & - & 0.19 \\
Kakara & 0.25 & 0.15 & 0.27 & - & 0.66 \\
Kumo & 0.02 & 0.05 & - & - & 0.07 \\
Pilawang & 0.02 & 0.02 & - & - & 0.04 \\
\hline
\end{tabular}

Notes : A $=$ Area $\left(\mathrm{km}^{2}\right), \mathrm{MA}=$ Mangrove Area $\left(\mathrm{km}^{2}\right)$.

Source : NDVI Using Landsat 8 OLI in QGIS.

based ecotourism development priorities. Meanwhile, NDVI can be implemented through the following equation:

$N D V I=\frac{\rho_{\mathrm{z}}-\rho_{1}}{\rho_{\mathrm{z}}+\rho_{1}}$

Notes : NDVI was normalized difference vegetation (NDVI), $\rho_{2}$ was near infrared (NIR), $\rho_{1}$ was Red (RED).

NDVI calculations will evaluate the value of mangrove tree density. Furthermore, the NDVI class values were reclassified into three classes: the rare, medium, and dense classes. The research location is divided into several zones, Tagalaya Island consists of four zones, Maiti and Kakara Islands consists of three zones, Kumo Island and Pilawang Cape consist of two zones. Each zone has a different area $\left(\mathrm{km}^{2}\right)$, as shown in the Table 2.

Table 2 shows an area of mangrove zone in each research location. Tagalaya Island has an area of $2,83 \mathrm{~km}^{2}$. In comparison, the mangrove area is $1,44 \mathrm{~km}^{2}$ $(50,87 \%)$ which is divided into four Zones with the following descriptions: Zone 1 has an area of $0,33 \mathrm{~km}^{2}(11,66 \%)$; Zone 2 has an area of $0,46 \mathrm{~km}^{2}(16,25 \%)$; Zones 3 has an area of $0,49 \mathrm{~km}^{2}(17,31 \%)$; Zone 4 has an area of $0,16 \mathrm{~km}^{2}(0,16 \%)$. Furthermore, Maiti Island has an area of $0,37 \mathrm{~km}^{2}$ while the mangrove area is $0,19 \mathrm{~km}^{2}(51,35 \%)$, which is divided into three Zones with the following descriptions: Zone 1 has an area of $0,06 \mathrm{~km}^{2}$ $(16,22 \%)$; Zone 2 has an area of $0,08 \mathrm{~km}^{2}$ $(21,62 \%)$; Zone 3 has an area of $0,05 \mathrm{~km}^{2}$ $(13,51 \%)$. Otherwise, Kakara Island has an area of $1,70 \mathrm{~km}^{2}$ while the mangrove area is
$0,66 \mathrm{~km}^{2}(38,82 \%)$, which is divided into three Zones with the following descriptions: Zone 1 has an area of $0,25 \mathrm{~km}^{2}(14,12 \%)$; Zone 2 has an area of $0,15 \mathrm{~km}^{2}(08,82 \%)$; Zone 3 has an area of $0,27 \mathrm{~km}^{2}(15,88 \%)$. In addition, Kumo Island has an area of 0,58 $\mathrm{km}^{2}$ while the mangrove area is $0,07 \mathrm{~km}^{2}$ $(12,07 \%)$, which is divided into two Zones with the following descriptions: Zone 1 has an area of $0,02 \mathrm{~km}^{2}(03,45 \%)$; Zone 2 has an area of $0,05 \mathrm{~km}^{2}(08,62 \%)$. Also, Pilawang Cape has an area of $0,07 \mathrm{~km}^{2}$ while the mangrove area is $0,04 \mathrm{~km}^{2}(57,14 \%)$, which is divided into two Zones with the following descriptions: Zone 1 has an area of $0,02 \mathrm{~km}^{2}$ $(28,57 \%)$; Zone 2 has an area of $0,02 \mathrm{~km}^{2}$ $(28,57 \%)$.

\subsection{Data Analysis: Trianggulation}

In the second stage, triangulation techniques are used to identify the coherence of interviews, observations and document studies. The results of mangrove distribution mapping are used to analyze the decisionmaking process for determining priority areas for community-based ecotourism development. Besides, sustainable livelihoods are used to analyze local communities' socio-cultural aspects in utilizing mangrove resources for sustainable livelihoods. The informants involved were SLR $\left(37^{\text {th }}\right)$ and BL $\left(40^{\text {th }}\right)$. Both are Kumo Island and Kakara Island residents who work as providers of sea transportation services (Ketinting), are active as village officials, and have routine activities as subsistence fishermen to meet food needs every day. 
Mangrove areas with sparse, medium and dense densities were visually documented using the Phantom 4 version 2 drone to adjust remote sensing results to mangrove conditions at the research location.

Table 3 shows documentation on Tagalaya Island, Kakara Island, Maiti Island, Kumo Island and Pilawang Cape. Access to the research location is taken by land and sea routes. The location of Pilawang Cape can be visited using land transportation, namely motorized vehicles and cars. Meanwhile, Kumo Island, Maiti Island, Kakara Island, and Tagalaya Island, can be visited by sea transportation, namely traditional boats (Ketinting). The estimated time to the research location, especially the island area, varies because of the route taken by sea transportation drivers, adjusting the direction of wind, waves and coral reef area. Geographical conditions and access between islands illustrate the dynamics of the livelihoods of coastal and island communities. Thus, sustainable livelihoods' framework becomes relevant for analyzing coping and survival strategies (Figure 3 ).

Figure 3 is a framework for the concept of sustainable livelihoods that is relevant to the context of this research. Mazibuko (2013) describes the existence of a context of vulnerability in the form of shocks, trends, seasonality that affect local people's access to livelihood assets (natural capital, physical capital, financial capital, social capital, human capital). Also, the mobility of local people's access to livelihood

Tabel 3. Documentation of field observation in research location.

\begin{tabular}{ll}
\hline & \multicolumn{1}{c}{ Location } \\
\hline Tagalaya & https://youtu.be/e_3aNY2c2i4 \\
Kakara & https://youtu.be/tKYgbE08OyY \\
Maiti & https://youtu.be/OLoBJSyL8sE \\
Kumo & https://youtu.be/EjiEWNm2LSg \\
Pilawang & https://youtu.be/CLTTCxMPubo \\
\hline
\end{tabular}

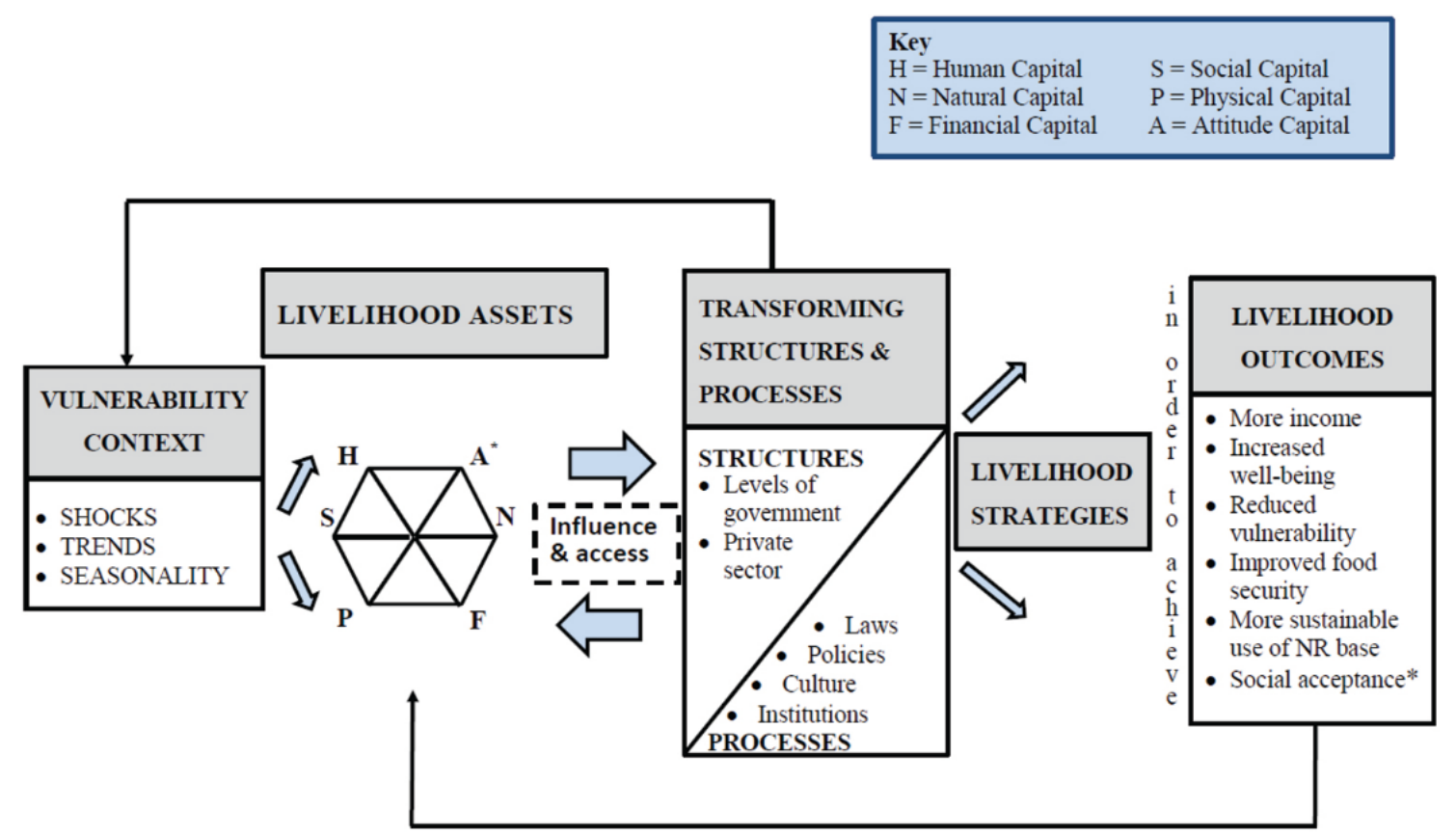

Figure 3. Sustainable Livelihood Approach (SLA) Framework. 
assets can be supported by the public and private sectors through policies and institutions. Thus, access to livelihood assets can increase income, reduce the context of vulnerability, and increase welfare to support sustainable livelihoods. Considering the coherence of empirical issues with a theoretical perspective, this research focuses specifically on describing how mangroves support community-based ecotourism's sustainability from a sustainable livelihood perspective.

\section{RESULTS AND DISCUSSION}

\subsection{Mangrove Distribution}

The distribution of mangroves in North Maluku has a different structure and composition. Akbar (2017) reported that the thickness and composition of mangrove species in Dodinga Bay vary widely. At zone one, the identified mangrove species were Rhizophora stylosa, R. apiculata, S. alba, Ceriops tagal, $X$. granatum, Avicennia officinalis, Bruguiera sexangula, A. alba, B. cylindrica. At zone two, the mangrove species identified were $R$. apiculata, S. alba, A. froridum, $C$. tagal, $A$. officinalis, $B$. cylindrica. Meanwhile, at zone three, identified mangrove species were $R$. apiculata, R. stylosa, S. alba, and C. tagal. This shows that each location (zone) has different characteristics of mangrove species. Mangrove growth is influenced by water and soil environmental conditions, which can be classified based on temperature, salinity, dissolved oxygen (DO), water $\mathrm{pH}$, soil $\mathrm{pH}$, and based mud (Akbar, 2017). Akbar et al. (2018) also pointed out the existence of terms used by local people to distinguish mangrove characteristics, as follows: Soki-Soki ( $R$. stylosa, $R$. apiculata, $R$. mucronata, C. tagal, B. cylindrica, A. froridum); Posi-Posi (X. granatum, Sonneratiaceae); Fika-Fika (A. marina). Akbar et al. (2015) also showed differences in mangrove ecosystems thickness (meters) based on location (zone).
Normalized difference vegetation index (NDVI) helps us identify mangrove density in Tagalaya Island, Pulau, Maiti, Kakara Island, Kumo Island, Pilawang Cape. Based on NDVI process, in 2013 the maximum vegetation density values identified at the research location are as follows: Tagalaya Island $(0,47)$; Pilawang Cape $(0,46)$; Maiti Island $(0,46)$; Kumo Island $(0,46)$; and Kakara Island $(0,46)$. Meanwhile, the minimum vegetation density values identified at the research location were as follows: Tagalaya Island $(-0,42)$; Pilawang Cape $(-0,09)$; Maiti Island $(-0,03)$; Kumo Island $(-0,03)$; Kakara Island $(-0,03)$. Compared to the results of the NDVI process in 2021, the maximum vegetation density values identified at the research location are as follows: Tagalaya Island $(0,48)$; Pilawang Cape $(0,41)$; Maiti Island $(0,48)$; Kumo Island $(0,46)$; and Kakara Island $(0,49)$. Meanwhile, the minimum vegetation density values identified at the research location were as follows: Tagalaya Island $(-0,03)$; Pilawang Cape $(0,09)$; Maiti Island $(-0,03)$; Kumo Island $(-0,18)$; Kakara Island $(-0,33)$. The average NDVI value at each research location needs to be specifically studied in the mangrove forest area which is divided into several zones.

The average NDVI value in Tagalaya Island (Figure 4), especially in Zone 1, Zone 2 and Zone 3, has experienced a significant increase from 2013 to 2021 . This can be seen from the average NDVI Zone 1 value in 2013 which was 0,371 which increased in 2021 to 0,383 . The average NDVI Zone 2 value in 2013 was 0,363 increasing to 0,369 in 2021. The average NDVI Zone 3 value in 2013 was 0,204 increasing to 0,219 in 2021 . Meanwhile, for Zone 4, the average NDVI value in 2013 was 0,371 decreased to 0,346 in 2021. Therefore, the condition of mangroves in Zone 4 of Tagalaya Island needs to be accommodated in preservation and conservation policies.

The average NDVI value in Kakara Island (Figure 5), especially in Zone 2 and 
Zone 3, has experienced a significant increase from 2013 to 2021 . This can be seen from the average NDVI Zone 2 value in 2013 which was 0,37 which increased in 2021 to 0,383 . The average NDVI Zone 3 value in 2013 was 0,378 increasing to 0,396 in 2021 . Meanwhile, for Zone 1, the average NDVI value in 2013 was 0,371 decreased to 0,346 in 2021. Therefore, the condition of mangroves in Zone 1 of Kakara Island needs to be accommodated in preservation and conservation policies.
The average NDVI value in Maiti Island (Figure 6), especially in Zone 1, Zone 2 and Zone 3, has experienced a significant increase from 2013 to 2021 . This can be seen from the average NDVI Zone 1 value in 2013 which was 0,327 which increased in 2021 to 0,383 . The average NDVI Zone 2 value in 2013 was 0,34 increasing to 0,364 in 2021. The average NDVI Zone 3 value in 2013 was 0,251 , increasing to 0,276 in 2021 . Thus, the condition of the mangrove forests on Maiti Island is getting better from 2013 to 2021.

\section{Mangrove Monitoring in Tagalaya Island (2013-2021)}

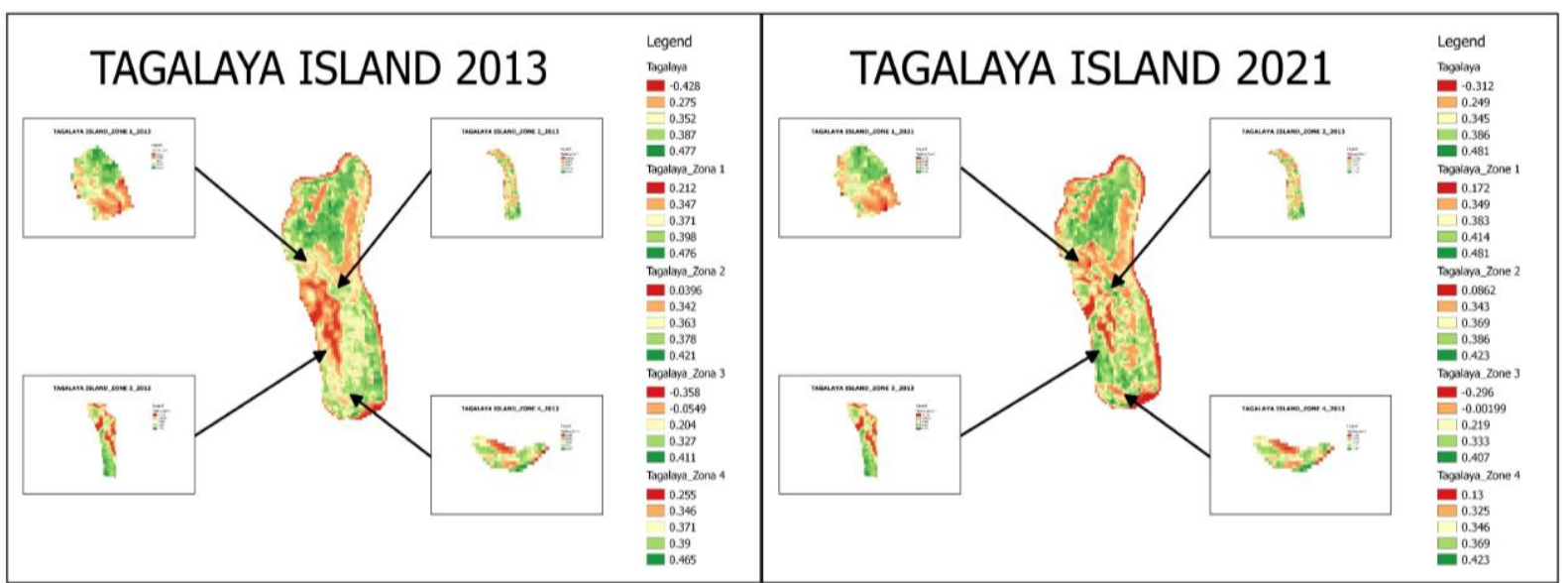

Figure 4. NDVI of Mangrove Distribution in Tagalaya Island from 2013-2021 (Source: NDVI Landsat 8 OLI uses QGIS 2.18.4).

\section{Mangrove Monitoring in Kakara Island (2013-2021)}

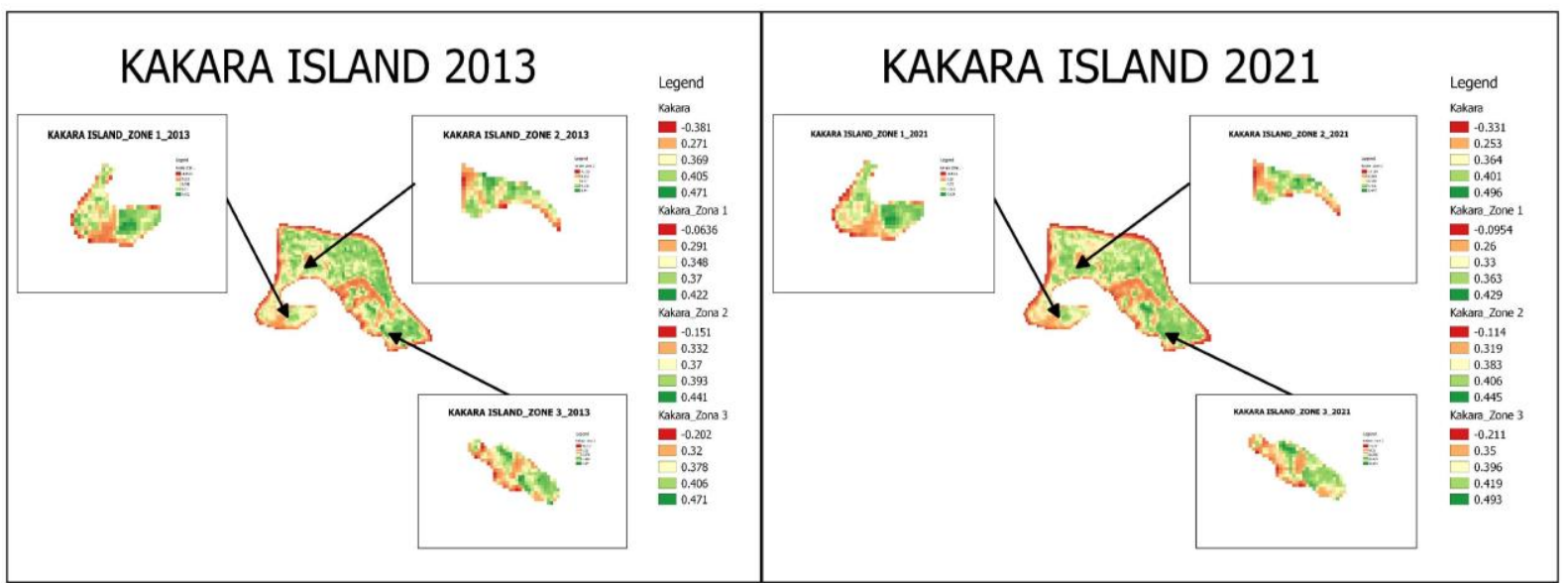

Figure 5. NDVI of Mangrove Distribution in Kakara Island from 2013-2021 (Source: NDVI Landsat 8 OLI uses QGIS 2.18.4). 
Mangrove Monitoring in Maiti Island (2013-2021)

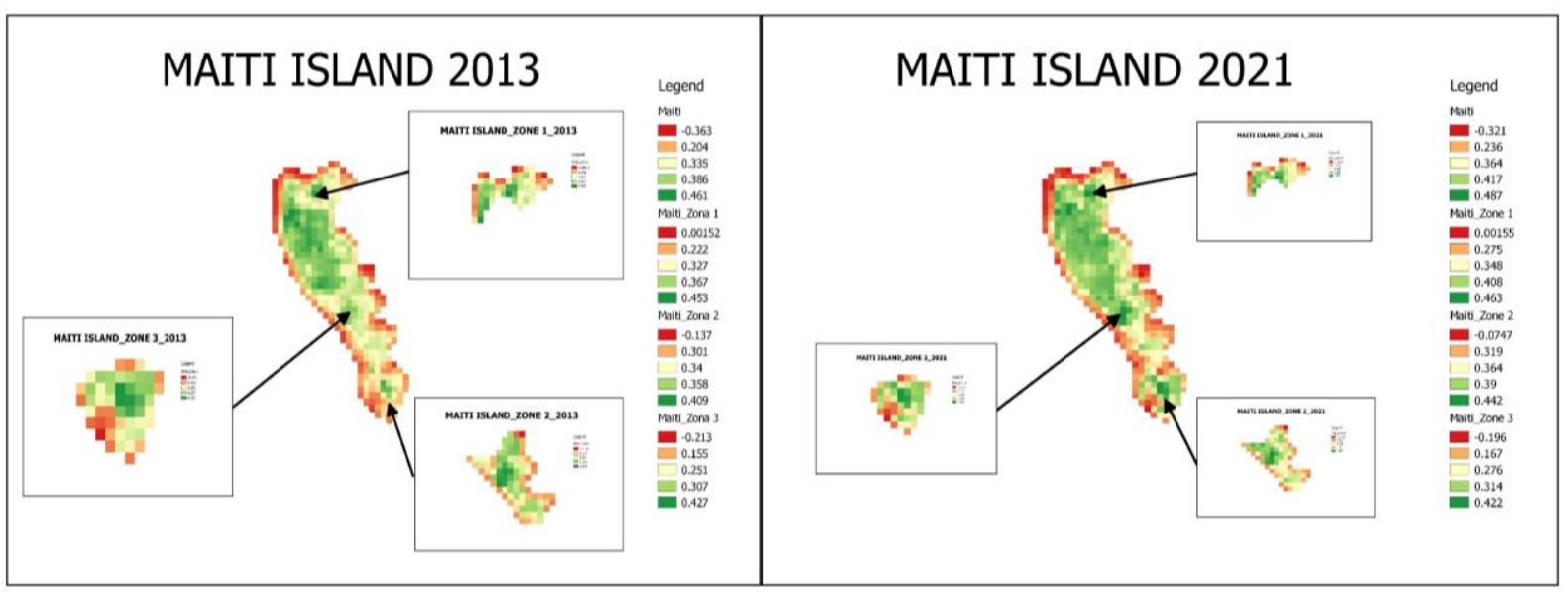

Figure 6. NDVI of Mangrove Distribution in Maiti Island from 2013-2021 (Source: NDVI Landsat 8 OLI uses QGIS 2.18.4).

Mangrove Monitoring in Kumo Island (2013-2021)

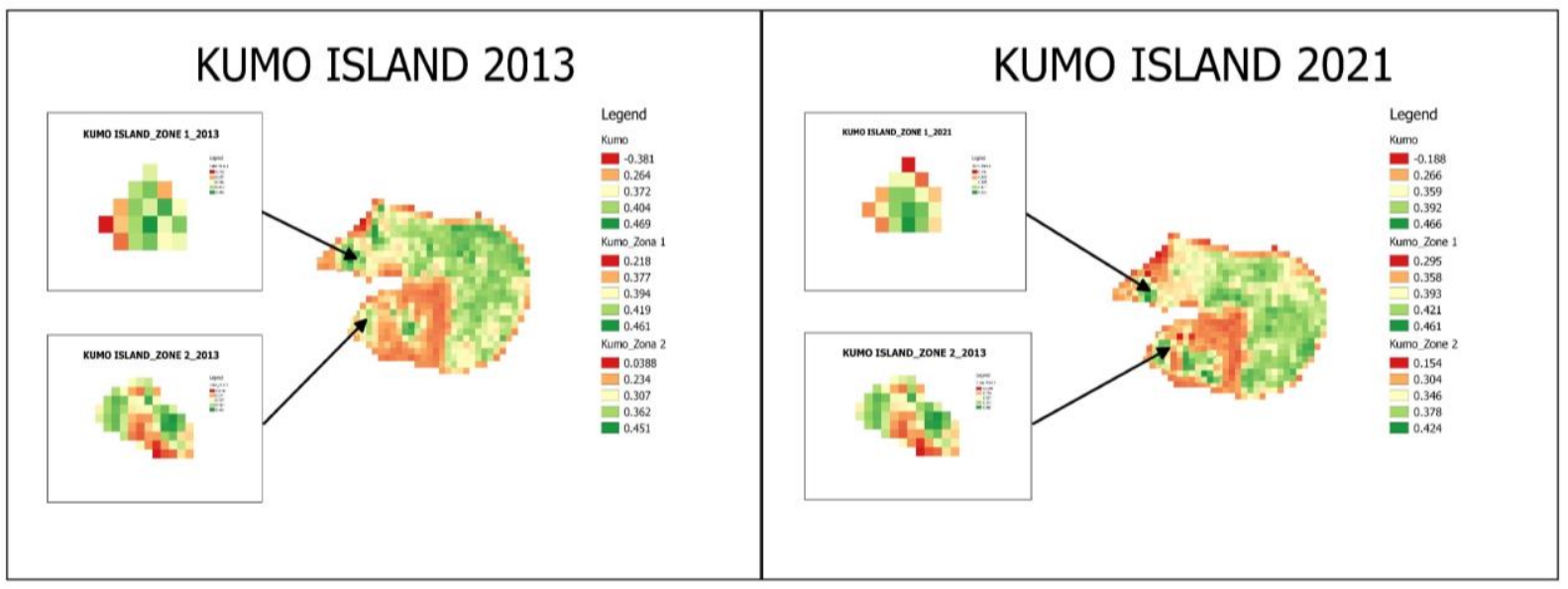

Figure 7. NDVI of Mangrove Distribution in Kumo Island from 2013-2021 (Source: NDVI Landsat 8 OLI uses QGIS 2.18.4).

The average NDVI value in Kumo Island (Figure 7), especially in Zone 2, has experienced a significant increase from 2013 to 2021. This can be seen from the average NDVI Zone 2 value in 2013 which was 0,307 which increased in 2021 to 0,346 . In addition, the average NDVI Zone 2 value in 2013, decreased from 0,394 to 0,393 in 2021. Therefore, the mangrove area in zone 1 of Kumo Island needs to be maintained and protected for its sustainability.
The average NDVI value in Pilawang Cape (Figure 8), especially in Zone 1 and Zone 2, experience a significant decline from 2013 to 2021. This can be seen from the average NDVI Zone 1 value in 2013 which was decreased from 0,25 to 0,193 in 2021. Also, the average NDVI Zone 2 value in 2013, decreased from 0,279 to 0,260 in 2021.

The decrease in the average value of NDVI in Pilawang Cape needs to be accommodated in the policy of preservation 
andconservation of mangrove areas. Furthermore, the categorization of the NDVI average value in each zone in the study location can be seen in Table 4 .

Table 4 shows that mangrove zone with the lowest NDVI value in 2021 is the Pilawang Cape, with the rare category. The distribution conditions and damage to mangrove ecosystems can be interpreted using Landsat 8 OLI imagery. Furthermore, Arnanto (2015) stated that the NDVI technique can classify vegetation indices based on zones. This shows that monitoring mangroves as an ecotourism area need to be done to recommend development priorities that support ecological sustainability and local communities' livelihoods. Based on the results of processing data from OLI Landsat 8 Satellite Imagery using the NDVI approach, the value of mangrove vegetation density based on the classification of zone in each research area.

\section{Mangrove Monitoring in Pilawang Cape (2013-2021)}

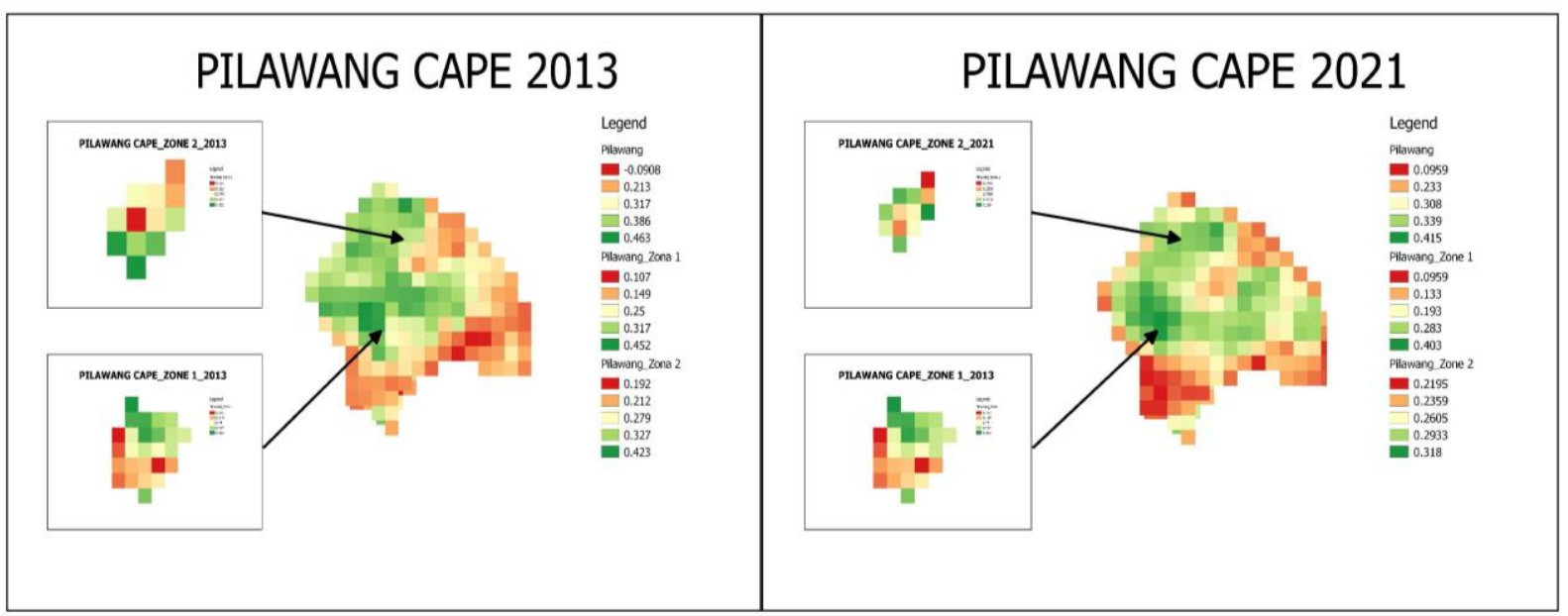

Figure 8. NDVI of Mangrove Distribution in Pilawang Cape from 2013-2021 (Source: NDVI Landsat 8 OLI uses QGIS 2.18.4).

Tabel 4. NDVI value in Research Location from 2013-2021.

\begin{tabular}{lllllllll}
\hline \multirow{2}{*}{ Location } & \multirow{2}{*}{ Tahun } & \multicolumn{9}{c}{ NDVI } & \multirow{2}{*}{ A } & \multirow{2}{*}{ C } \\
\cline { 3 - 6 } & & Zone 1 & Zone 2 & Zone 3 & Zone 4 & & \\
\hline \multirow{2}{*}{ Tagalaya } & 2013 & 0.371 & 0.363 & 0.204 & 0.371 & 0.327 & Rare \\
\multirow{2}{*}{ Maiti } & 2021 & 0.383 & 0.369 & 0.219 & 0.346 & 0.329 & Rare \\
& 2013 & 0.327 & 0.34 & 0.251 & - & 0.306 & Rare \\
Kakara & 2021 & 0.348 & 0.364 & 0.276 & - & 0.329 & Rare \\
& 2013 & 0.348 & 0.37 & 0.378 & - & 0.365 & Moderate \\
Kumo & 2021 & 0.33 & 0.383 & 0.396 & - & 0.369 & Moderate \\
& 2013 & 0.394 & 0.307 & - & - & 0.350 & Moderate \\
Pilawang & 2021 & 0.393 & 0.346 & - & - & 0.369 & Moderate \\
& 2013 & 0.25 & 0.279 & - & - & 0.264 & Rare \\
\hline
\end{tabular}

Notes $:$ NDVI $=$ Normalized Difference Vegetation, $\mathrm{A}=$ Average, $\mathrm{C}=$ Criteria

Source : NDVI Using Landsat 8 OLI 2013-2021 in QGIS 2.18.4. 
Interpretation of the distribution and condition of mangrove in Tagalaya Island, Kakara Island, Maiti Island, Kumo Island and Pilawang Cape shows moderate and rare criteria. Dalengkade (2020a; 2020b) shows that humidity, lighting intensity, and temperature support mangrove growth in North Halmahera Regency. Several studies on mangroves in North Maluku also show a relationship between local knowledge and the sustainability of mangrove areas (Haya et al., 2015; Serosero et al., 2009; Hasan et al., 2020; Tahir et al., 2017). The mangrove area is also believed to be a livelihood source for people in North Halmahera Regency because it supports other animal habitats, such as the Maluku Gosong Bird (i) (Kondo et al., 2018).

As a support for the livelihoods of people in coastal areas and archipelago areas, Mangroves are also developed as an attraction for North Halmahera Regency through the concept of ecotourism. Ferse et al. (2012) show that the implementation of ecotourism development can provide economic benefits and open access for coastal and island communities as fishers to obtain financial capital. Meanwhile, Bergman \& Ramqvist (2017) also reported that ecotourism will have a wider impact on people who work as fishermen and farmers. Even though ecotourism is considered effective as an ecology-based approach, mangroves' sustainability needs to be protected from illegal logging activities by irresponsible people. The involvement of local communities in maintaining mangrove areas through ecotourism is the most effective strategy for the sustainability of community livelihoods in the North Halmahera Regency. Community-based ecotourism development is priority and recommended for mangrove sustainability and the livelihood of local communities. Based on the vegetation index's value in the archipelago, the development of ecotourism on Pilawang Cape at zone 1 and zone 2 needs to be prioritized.

\subsection{Sustainable Livelihood through Ecotourism : Sustainable Livelihood Framework}

The context of vulnerability that affects the livelihoods of coastal and island communities in the North Halmahera Regency can be classified into three parts, namely shock, trend and seasonality. Shock can be in the form of a natural disaster or the Covid-19 pandemic. Besides, seasonality and trend can be in the form of an indeterminate rainy season that hinders coastal communities' livelihoods as subsistence fishermen and short-term crop farmers. On the other hand, the trend in the form of fluctuation in copra's purchasing price also affects the community's livelihoods as coconut plantation farmers sell copra to collectors. Phuong et al. (2018) stated that people in coastal areas can take advantage of small-scale agricultural activities as a strategy to maintain household livelihoods against climate change. Meanwhile, Bennett et al. (2020) show the vulnerability of the Covid-19 pandemic, which affects subsistence fishermen's livelihoods. Therefore, the coastal environment's ecological authenticity needs to be maintained by involving local communities (Rogers \& Monks, 2016). Thus, the context of vulnerability in North Halmahera District needs to be neutralized to sustain local community livelihoods.

The North Halmahera Regency people have collective values, namely the Hibualamo cultural norms as fundamental values in social interaction. Hibualamo (Big House) has a symbolic meaning related to social networks and communal habitus in the form of local wisdom of Hohidiai, Hirono, Makiriwo as a manifestation of the value of complete brotherhood (Pedersen, 2016). Hibualamo cultural norms can be interpreted as local wisdom that influences local communities' coping strategies and survival strategies (Handoko \& Mujabuddawat, 2017). As a community living in coastal areas, the fishing tradition is dominant and is 
related to the people's cultural rites in North Halmahera Regency. Also, history has recorded that there was intervention by foreign countries in 1250-1950 related to the cultivation of coconut commodities which were economically valuable to be transacted, thus affecting the livelihoods of people in North Halmahera Regency as farmers in coconut plantations (Amal, 2006). North Halmahera community settlements can be classified as settlement areas in coastal areas, islands, watersheds, and deepening. Although the archipelago's land area is minimal, deep coconut farming activities and copra production are still carried out by local people to maintain their livelihoods.

In the context of the Pilawang Cape coastal community, the most dominant forms of capital to support local communities' sustainability are human capital and social capital. Communities who live around Pilawang Cape have the capability of access to wider plantation land (natural capital), financial support and access to markets for trading activities (financial capital), physical infrastructure to support livelihoods (physical capital), higher education (human capital). And adhering to the collective values of the Hibualamo indigenous people (social capital). This is different from the people who live on Kumo Island, Kakara Island and Tagalaya Island, where capital to sustain their livelihoods depends on social and natural capital. The capability to access social and natural capital becomes dominant because of the mobility of land use in the archipelago, supported by the collective action of customary rituals in the form of cooperation activities. However, the obstacle for people in the archipelago is the limited mobility of access to higher education (human capital) which is related to the level of per-capita income (financial capital) and the availability of supporting infrastructure (physical capital). As the results of the interview with BL (40 years) are as follows:
"I live on Kumo Island, my job every day is a labor at the port. If there is no boat, I work as a ketinting boat driver. Besides that, I also have a coconut plantation land that was inherited by my parents to be managed as a provision for life in the future. I also do subsistence fishing activities to fulfill my family's daily food. One week I can earn IDR 500,000 - IDR 1,500,000 to bring visitors to tourist attractions. Meanwhile, the ticket per person is set at IDR 5,000. Sometimes it is crowded with visitors, sometimes it is quiet. But the loneliest thing was during the Covid-19 Pandemic. My income is also used for the educational needs of my children. I am very grateful that no one fell ill, because medical expenses will be very difficult for me to get during this pandemic."

Based on the interviews with the key informant BL (40 years), it can be seen that there are obstacles to the livelihood of the community in the archipelago which are related to the context of vulnerability. It is necessary to support policies and institutions that can mobilize community access to resources and maintain sustainability in the context of improving the community's economy in the North Halmahera Regency. This shows that mangroves have not only ecological value but also economic value. Through the Tourism Office in North Halmahera Regency through the 2016-2021 Plans and Strategies, the Regional Government has established policies for developing tourism destinations, tourism marketing, and the creative economy and budget support to fix, optimize and maintain infrastructure to support tourism activities. The Regional Tourism Office also builds partnerships with institutions or communities at the village level to collaborate in achieving the vision and mission of regional tourism development. Thus, policies and institutions play a critical role in the sustainability of the tourism sector, which supports people's livelihoods in rural, coastal and archipelagic areas. 
Institutionally, the development of tourism destinations in the North Halmahera Regency can be viewed based on managers' classification, either individually, in groups or through formal institutions. In the context of developing community-based mangrove ecotourism on Kumo Island, Kakara Island, and Tagalaya Island, direct and intensive assistance from the Tourism Office is needed, considering the limited access of people in the islands to formal and informal education (human capital) related to the managerial aspects of the mangrove area. For tourism development, spatial use patterns in coastal areas support sustainable livelihoods. As the results of the interview with SLR $\left(37^{\text {th }}\right)$ are as follows:

"Maiti Island is uninhabited. However, the land on the island belongs to the people living in Kakara, Tagalaya and Kumo. Of course there is a history of land ownership on the island. The land on Maiti Island is used for the plantation area of Kelapa Dalam, as well as other plantation crops. Likewise, the land on the islands of Tagalaya, Kakara and Kumo is used for deep coconut plantations. It is not as large as the land on the mainland of Halmahera (Tobelo City), at least it is sufficient to meet daily needs. Regarding mangroves, prior to the socialization of the prohibition on mangrove logging, there was a tendency for local people to cut and take mangrove wood as fuel in the kitchen at home, or to sell it to the market. With the development of ecotourism, the Tourism Office and the Ministry of Marine Affairs and Coastal Fisheries have conducted socialization related to the ecological benefits of mangroves and involve the community in improving the economy through the tourism sector. When mangroves become a tourist attraction, local people become aware of protecting the sustainability of mangroves on the islands of Kumo, Kakara, Maiti and Tagalaya."

Mangroves have ecological benefits for environmental restoration in coastal areas and islands (Buisson et al., 2014). The existence of mangroves is important to reduce the level of vulnerability to disasters caused by ocean waves, such as tsunamis
(McElduff et al., 2016). Therefore, communities' involvement in coastal areas and islands to protect the sustainability of mangroves is important (Bergman \& Ramqvist, 2017; Duggan \& White, 2010; Tajima et al., 2017). On the other hand, changes in mangrove areas and land use in waters can be analyzed using spatial data (Hossain et al., 2020; Macedo et al., 2010; Udo et al., 2016). Fraser et al., (2017) show that the use of Geographic Information Systems (GIS) for monitoring land use in coastal areas is beneficial in identifying the carrying capacity of the environment, the presence of buildings, and erosion that occurs on the shoreline. Also, Xu et al., (2016) also showed that spatial data is useful in classifying coastal ecosystems and identifies the factors that influence their sustainability.

Community-based ecotourism is an ideal concept that can maintain mangroves' sustainability, increase per-capita income, create jobs, and create sustainable livelihoods. Mondino \& Beery (2019) argue that ecotourism is a learning tool for sustainable development. On the other hand, Mendes et al. (2019) show that ecotourism is effective in maintaining the sustainability of mangroves and plays an important role in protecting animals in the area. Community involvement in Kumo Island, Kakara Island, and Tagalaya Island in developing ecotourism is also an educational process to accumulate human capital, namely increasing human resources quality in tourism destination management (King et al., 2020). Besides, Diamantis (2018) shows that collaboration between stakeholders is essential for implementing ecotourism.

The people's livelihoods in the North Halmahera Regency, which are closely related to collective values (Hibualamo), reflect the socio-economic behaviour embodied in the pattern of resource use to sustain livelihoods. Beall et al. (2020) argue that the consumption of natural resources represents the cultural values of society. Therefore, it is necessary to synergize the 
socio-cultural values with the institutional dimension. Pellis (2019) shows that conceptually, ecotourism is implemented to prevent conflicts of interest between sectors related to land resources use in coastal and island areas. In fact, some researchers show a conflict of interest in the implementation of the ecotourism concept (Büscher et al., 2017; Fletcher, 2019). However, ecotourism is an appropriate concept in protecting coastal areas and is relevant to the socio-cultural context of the Hibualamo community.

\section{CONCLUSION}

Mangroves play an important role as a natural resource that provides ecological benefits and has economic value. Based on the identification results of the distribution of mangroves on Tagalaya Island, Kakara Island, Maiti Island, Kumo Island, and Pilawang Cape, it is still dominated by rare instead of moderate criteria the indicators stipulated by the Decree of the Minister of State for the Environment in 2004. This finding shows that Pilawang Cape has the lowest NDVI value. The average NDVI value in 2021 is 0,226 which can be categorized as a rare mangrove forest according to the mangrove standard damage criteria. Thus, Mangrove area in Pilawang Cape needs to be prioritized as a preservation and conservation strategy through community-based ecotourism concept. The implementation of community-based ecotourism concept aims to increase local communities' participation in protecting and maintaining mangroves sustainability through the tourism sector. Mangroves can be optimized to increase per-capita income, reduce the context of vulnerability, increase welfare, and create sustainable livelihoods. Institutionally, the optimization of mangrove areas as a tourist attraction can be managed by the community and the village government through Village-Owned Enterprises. In the socio-cultural context, the North Halmahera Regency people have cultural values embodied in local wisdom, namely Hohidiai (cooperation), to maintain the environmental sustainability. Thus, this study's results can be used as recommendations for regional tourism development policies based on spatial data that are relevant to the socio-cultural context, especially ecotourism in North Halmahera Regency.

\section{ACKNOWLEDGMENTS}

Thank you to the Atma Jaya Catholic University of Indonesia, LLDIKTI Region III and Satya Wacana Christian University, LLDIKTI Region VI, to complete the research process to scientific publication. To all parties involved as key informants, we thank you very much.

\section{REFERENCES}

Akbar, N., B. Abdurrachman, \& T. Irmalita. 2015. Struktur komunitas ekosistem mangrove di Kawasan Pesisir Sidangoli Kabupaten Halmahera Barat, Maluku Utara. Depik, 4(3): 132-143. https://doi.org/10.13170/depik.4.3.30 52

Akbar, N., A. Ibrahim, I. Haji, I. Tahir, F. Ismail, M. Ahmad, \& R. Kotta. 2018. Struktur komunitas mangrove di Desa Tewe, Kecamatan Jailolo Selatan, Kabupaten Halmahera Barat Provinsi Maluku Utara. J. Enggano, 3(1): 8197.

https://doi.org/10.31186/jenggano.3.1 .81-97

Akbar, N., I. Marus, I. Haji, S. Abdullah, S. Umalekhoa, F.S. Ibrahim, M. Ahmad, A. Ibrahim, A. Kahar, \& I. Tahir. 2017. Struktur komunitas hutan mangrove di Teluk Dodinga, Kabupaten Halmahera Barat Provinsi Maluku Utara. J. Enggano, 2(1): 10114. https://doi.org/10.31186/jenggano.2.1 
$.78-89$

Amal, A.M. 2006. Kepulauan rempahrempah: Perjalanan sejarah Maluku Utara 1250-1950. Gramedia, 10-14 pp.

Analuddin, K., A. Septiana, Nasaruddin, Y. Sabilu, \& S. Sharma. 2019. Mangrove fruit bioprospecting: nutritional and antioxidant potential as a food source for coastal communities in the Rawa Aopa Watumohai National Park, Southeast Sulawesi, Indonesia. International J. of Fruit Science, 19(4): 423-436.

https://doi.org/10.1080/15538362.201

8.1555507

Arjasakusuma, S., Y. Yamaguchi, T. Nakaji, Y. Kosugi, S.A. Shamsuddin, \& M. Lion. 2018. Assessment of values and trends in coarse spatial resolution NDVI datasets in Southeast Asia landscapes. European J. of Remote Sensing, 51(1): 863-877.

https://doi.org/10.1080/22797254.201 8.1496799

Arnanto, A. 2015. Pemanfaatan transformasi Normalized Difference Vegetation Index (NDVI) Citra Landsat TM untuk zonasi vegetasi di lereng merapi bagian selatan. Geomedia, 11(2): 155-170. https://doi.org/10.21831/gm.v11i2.34 48

Beall, J.M., B.B. Boley, A.C. Landon, \& K.M. Woosnam. 2020. What drives ecotourism: environmental values or symbolic conspicuous consumption? J. of Sustainable Tourism, 0(0): 1-20. https://doi.org/10.1080/09669582.202 0.1825458

Bennett, N.J., E.M. Finkbeiner, N.C. Ban, D. Belhabib, S.D. Jupiter, J.N. Kittinger, S. Mangubhai, J. Scholtens, D. Gill, \& P. Christie. 2020. The COVID-19 pandemic, small-scale fisheries and coastal fishing communities. Coastal Management, 48(4): 336-347. https://doi.org/10.1080/08920753.202
0.1766937

Bergman, I. \& P.H. Ramqvist. 2017. Farmerfishermen: interior lake fishing and inter-cultural and intra-cultural relations among coastal and interior Sámi communities in Northern Sweden. Acta Borealia, 34(2): 134158. https://doi.org/10.1080/08003831.201 7.1390662

Bhavsar, D., A. Kumar, \& A. Roy. 2017. Applicability of NDVI temporal database for Western Himalaya forest mapping using Fuzzy-Based PCM classifier. European J. of Remote Sensing, 50(1): 614-625. https://doi.org/10.1080/22797254.201 7.1379363

Buisson, E., P. Bravet, J. Mieusset, N. Baillot, C. Dubreucq, L. Sadonès, J. Chenot, \& L. Brun. 2014. Plant communities of a coastal lagoon Foredune: definition of the reference and restoration after compaction. Acta Botanica Gallica, 161(3): 277-286. https://doi.org/10.1080/12538078.201 4.919875

Bulmer, R.H., M. Lewis, E.O'Donnell, \& C.J. Lundquist. 2017. Assessing mangrove clearance methods to minimize adverse impacts and maximize the potential to achieve restoration objectives. New Zealand J. of Marine and Freshwater Research, 51(1): 110-126.

https://doi.org/10.1080/00288330.201 6.1260605

Büscher, B., R.V.D. Bremer, R. Fletcher, \& S. Koot. 2017. Authenticity and the contradictions of the 'ecotourism script': global marketing and local politics in Ghana. Critical Arts, 31(4): 37-52.

https://doi.org/10.1080/02560046.201 7.1386697

Carrasco-Benavides, M., M. Mora, G. Maldonado, J. Olguín-Cáceres, E.V. Bennewitz, S. Ortega-Farías, J. 
Gajardo, \& S. Fuentes. 2016. Assessment of an automated digital method to estimate Leaf Area Index (LAI) in cherry trees. New Zealand $J$. of Crop and Horticultural Science, 44(4): 247-261. https://doi.org/10.1080/01140671.201 6.1207670

Chai-Arayalert, S. 2020. Smart application of learning ecotourism for young ecotourists. Cogent Social Sciences, 6(1): 1-10. https://doi.org/10.1080/23311886.202 0.1772558

Cheung, L.T.O. \& C.Y. Jim. 2013. Ecotourism service preference and management in Hong Kong. International J. of Sustainable Development and World Ecology, 20(2): 182-194.

https://doi.org/10.1080/13504509.201 3.775192

Dalengkade, M.N. 2020a. Fluktuasi temporal kelembaban udara di dalam dan luar ekosistem mangrove. BAREKENG: J. Ilmu Matematika dan Terapan, 14(2): 159-166. https://doi.org/10.30598/barekengvol 14iss2pp159-166

Dalengkade, M.N. 2020b. Profile 24 jam kuat penerangan, suhu udara, kelembaban udara di luar dan di dalam hutan mangrove. BAREKENG: J. Ilmu Matematika dan Terapan, 14(1): 47-57.

https://doi.org/10.30598/barekengvol 14iss1pp047058

Datta, D. \& S. Deb. 2012. Analysis of coastal land use/land cover changes in the Indian sunderbans using remotely sensed data. Geo-Spatial Information Science, 15(4): 241-250. https://doi.org/10.1080/10095020.201 2.714104

Diamantis, D. 2018. Stakeholder ecotourism management: exchanges, coordination's and adaptations. $J$. of Ecotourism, 17(3): 203-205. https://doi.org/10.1080/14724049.201 8.1502122

Duggan, I.C. \& M.A. White. 2010. Consequences of human-mediated marine intrusions on the zooplankton community of a temperate coastal lagoon. New Zealand J. of Marine and Freshwater Research, 44(1): 1728.

https://doi.org/10.1080/00288331003 641661

Ferse, S.C.A., L. Knittweis, G. Krause, A. Maddusila, \& M. Glaser. 2012. Livelihoods of ornamental coral fishermen in South Sulawesi/ Indonesia: implications for management. Coastal Management, 40(5): 25-55. https://doi.org/10.1080/08920753.201 2.694801

Fletcher, R. 2019. Ecotourism after nature: anthropocene tourism as a new capitalist 'fix'. J. of Sustainable Tourism, 27(4): 22-35. https://doi.org/10.1080/09669582.201 8.1471084

Fraser, C., P. Bernatchez, \& S. Dugas. 2017. Development of a GIS coastal landuse planning tool for coastal erosion adaptation based on the exposure of buildings and infrastructure to coastal erosion, Québec, Canada. Geomatics, Natural Hazards and Risk, 8(2): 1125.

https://doi.org/10.1080/19475705.201 7.1294114

Glenn, D.M. \& A. Tabb. 2019. Evaluation of five methods to measure Normalized Difference Vegetation Index (NDVI) in apple and citrus. International J. of Fruit Science, 19(2): 191-210. https://doi.org/10.1080/15538362.201 8.1502720

Guha, S., H. Govil, A. Dey, \& N. Gill. 2018. Analytical study of land surface temperature with NDVI and NDBI using Landsat 8 OLI and TIRS data in Florence and Naples City, Italy. 
European J. of Remote Sensing, 51(1): 67-78.

https://doi.org/10.1080/22797254.201

8.1474494

Handoko, W. \& M.A. Mujabuddawat. 2017. Situs kampung tua Kao: identitas asal usul dan jejak peradaban islam di wilayah pedalaman Halmahera Utara. J. Pendidikan dan Kebudayaan, 2(2): 150-156.

https://doi.org/10.24832/jpnk.v2i2.65 3

Hasan, S., R.H. Serosero, \& S. Abubakar. 2020. Distribusi vertikal dan komposisi moluska pada ekosistem hutan di gugusan pulau-pulau Sidangoli Kabupaten Halmahera Barat Provinsi Maluku Utara. $J$. Agribisnis Perikanan, 13(1): 29-37. https://doi.org/10.29239/j.agrikan.13. 2.

Haya, N., N.P. Zamani, \& D. Soedharma. 2015. Analisis struktur ekosistem mangrove di Desa Kukupang Kecamatan Kepulawan Joronga. Teknologi Perikanan dan Kelautan, 6(1): 79-89. https://doi.org/10.24319/jtpk.6.79-89

Hossain, M.S., A.K. Gain, \& K.G. Rogers. 2020. Sustainable coastal socialecological systems: how do we define 'coastal'? International J. of Sustainable Development and World Ecology, 27(7): 1-6.

https://doi.org/10.1080/13504509.202 0.1789775

Islam, M.M., H. Borgqvist, \& L. Kumar. 2019. Monitoring mangrove forest landcover changes in the coastline of Bangladesh from 1976 to 2015. Geocarto International, 34(13): 1458-1476.

https://doi.org/10.1080/10106049.201 8.1489423

Joel, E.L. \& V.B. Bhimba. 2013. Evaluation of secondary metabolites from mangrove associated fungi Meyerozyma guilliermondii.
Alexandria J. of Medicine, 49(3): 189-194.

https://doi.org/10.1016/j.ajme.2013.0 4.003

Ministry of Environment and Forestry. 2004. Kriteria Baku dan Pedoman dan Penentuan Kerusakan Mangrove tahun 2004. KLHK. Jakarta. 201 p. http://perpustakaan.menlhk.go.id/pust aka/home/index.php?page $=$ ebook\&co $\mathrm{de}=\mathrm{kp} \& \mathrm{view}=\mathrm{yes} \& \mathrm{id}=58$

Kganyago, M., P. Mhangara, T. Alexandridis, G. Laneve, G. Ovakoglou, \& N. Mashiyi. 2020. Validation of sentinel-2 Leaf Area Index (LAI) product derived from snap toolbox and its comparison with global LAI products in an African semi-arid agricultural landscape. Remote Sensing Letters, 11(10): 883892.

https://doi.org/10.1080/2150704X.20 20.1767823

King, H., J.C. García-Rosell, \& S. Noakes. 2020. Promoting children-nature relations through play-based learning in ecotourism sites. J. of Teaching in Travel and Tourism, 20(3): 190-201. https://doi.org/10.1080/15313220.202 0.1797612

Kondo, L.R., Sunarno, O.F.W. Tutupary, B.R. Toisutta, \& B. Sadjab. 2018. Konservasi burung Gosong Maluku (Eulipoa wallacei) berbasis masyarakat di Desa Simau, Kecamatan Galela. J. Hutan PulauPulau Kecil, 2(2): 195-200.

https://doi.org/10.30598/jhppk.2018.2 .2 .195

Kushnir, V., F. Kogan, G. Korotaev, \& A. Powell. 2010. Predicting natural disasters in the coastal zone based on links between land and marine ecosystems. Geomatics: Natural Hazards and Risk, 1(3): 185-197. https://doi.org/10.1080/19475705.201 0.498146

Li, J.L., X. Sun, L. Chen, \& L.D. Guo. 2016. 
Community structure of Endophytic fungi of four mangrove species in Southern China. Mycology, 7(4): 180-190.

https://doi.org/10.1080/21501203.201 6.1258439

Li, T., F. Liu, \& G. N. Soutar. 2020. Experiences and value perceptions of an ecotourism trip-an empirical study of outbound Chinese tourists. Tourism Recreation Research, 0(0): 1-12. https://doi.org/10.1080/02508281.202 0.1804736

Macedo, J.A., P. Alves, Â. Lomba, J. Vicente, R. Henriques, H. Granja, \& J. Honrado. 2010. On the interest of plant functional classifications to study community-level effects of increased disturbance on Coastal Dune vegetation. J. Acta Botanica Gallica, 157(2): 305-315.

https://doi.org/10.1080/12538078.201 0.10516208

Marois, D.E. \& W.J. Mitsch. 2015. Coastal protection from tsunamis and cyclones provided by mangrove wetlands - a review. International $J$. of Biodiversity Science, Ecosystem Services and Management, 11(1): 7183.

https://doi.org/10.1080/21513732.201 4.997292

Mazibuko, S. 2013. Understanding underdevelopment through the sustainable livelihoods approach. $J$. Community Development, 44(2): 173187.

https://doi.org/10.1080/15575330.201 2.683798

McElduff, L., D. Peel, H. Ritchie, \& M. G. Lloyd. 2016. The octagon values model: community resilience and coastal regeneration. J. Urban, Planning and Transport Research, 4(1): $1-25$.

https://doi.org/10.1080/21650020.201 5.1124735
Mendes, S., J. Martins, \& T. Mouga. 2019. Ecotourism based on the observation of sea turtles-a sustainable solution for the touristic promotion of São Tomé and Príncipe. J. Cogent Social Sciences, 5(1): 1-16. https://doi.org/10.1080/23311886.201 9.1696001

Mo, X.S.L., Z. Lin, S. Wang, \& S. Hu. 2015. Trends in land surface evapotranspiration accros China with remotely sensed NDVI and climatological data for 1981-2010. $J$. J. Hydrological Sciences, 60(12): 2163-2177.

https://doi.org/10.1080/02626667.201 4.950579

Mondino, E. \& T. Beery. 2019. Ecotourism as a learning tool for sustainable development. The case of Monviso transboundary biosphere reserve, Italy. J. of Ecotourism, 18(2): 107121.

https://doi.org/10.1080/14724049.201 8.1462371

Pedersen, L. 2016. Religious pluralism in Indonesia. Asia Pacific J. of Anthropology, 17(5): 387-398. https://doi.org/10.1080/14442213.201 6.1218534

Pellis, A. 2019. Reality effects of conflict avoidance in rewilding and ecotourism practices-the case of Western Iberia. J. of Ecotourism, 18(4): 316-331.

https://doi.org/10.1080/14724049.201 9.1579824

Phuong, L.T.H., G.R. Biesbroek, L.T.H. Sen, \& A.E.J. Wals. 2018. Understanding smallholder farmers' capacity to respond to climate change in a coastal community in central Vietnam. Climate and Development, 10(8): 701-716.

https://doi.org/10.1080/17565529.201 7.1411240

Qiu, B., W. Li, M. Zhong, Z. Tang, \& C. Chen. 2014. Spatiotemporal analysis 
of vegetation variability and its relationship with climate change in China. Geo-Spatial Information Science, 17(3): 170-180.

https://doi.org/10.1080/10095020.201 4.959095

Rogers, G.M. \& A. Monks. 2016. Restoring lost ecological function: ecological surrogates facilitate maintenance of coastal Turf communities. New Zealand J. of Botany, 54(4): 393-411. https://doi.org/10.1080/0028825X.20 16.1216866

Serosero, R.H., S. Abubakar, \& S. Hasan. 2009. Distribution and community structure of mangrove in Donrotu, Guratu and Manomadehe Island, West Halmahera District, North Maluku. J. Ilmu dan Teknologi Kelautan Tropis, 12(1): 151-166. https://doi.org/10.29244/jitkt.v12i1.26 929

Singgalen, Y.A. 2020. Mangrove forest utilization for sustainable livelihood through community-based ecotourism in Kao Village of North Halmahera District. J. Manajemen Hutan Tropika, 26(2): 155-168. https://doi.org/10.7226/JTFM.26.2.15 5

Singgalen, Y.A., G. Sasongko, \& G.P. Wiloso. 2017. Institutional analysis of community-based tourism's sustainability (Case of KASBI community in North Halmahera). Sodality 6(3): 198-200. https://doi.org/10.22500/sodality.v6i3 .20744

Singgalen, Y.A., G. Sasongko, \& G.P. Wiloso. 2018. Tourism destination in remote area : problems and challenges of tourism development in North Halmahera as remote and border areas of Indonesia-Philippines. $J$. of Indonesian Tourism and Development Studies, 6(3): 175-86.

https://doi.org/10.21776/ub.jitode.201 8.006.03.04
Singgalen, Y.A., G. Sasongko, \& G.P. Wiloso. 2019a. Community participation in festival and digital tourism campaign (Case of North Halmahera District, Indonesia). J. of Indonesian Tourism and Development Studies, 7(1): 21-31. https://doi.org/10.21776/ub.jitode.201 9.007.01.04

Singgalen, Y.A., G. Sasongko, \& G.P. Wiloso. 2019b. Community participation in regional tourism development : a case study in North Halmahera regency - Indonesia. Insight Into Regional Development, 1(4): 318-33. https://doi.org/10.9770/ird.2019

Singgalen, Y.A., G. Sasongko, \& G.P. Wiloso. 2019c. Ritual capital for rural livelihood and sustainable tourism development in Indonesia. $J$. of Tropical Forest Management, 25(2): 115-25. https://doi.org/10.7226/jtfm.25.2.115

Singgalen, Y.A., G. Sasongko, \& G.P. Wiloso. 2019d. Social capital and livelihood diversification: tourism entrepreneurship in a remote area of North Halmahera, Indonesia. KAWISTARA, 9(3): 285-98. https://doi.org/10.22146/kawistara.34 627

Singgalen, Y.A. \& S.M. Simange. 2018. Livelihood and Rural Tourism Development in Coastal Area North Maluku Province Indonesia. International Conference on Frontier of Science and Society (ICFSS-2017), Makasar, Indonesia, 3-5 November 2017, 1-10 pp. https://doi.org/10.1088/17551315/156/1/012010

Tahir, I., R.E. Paembonan, Z.A. Harahap, N. Akbar, \& E.S. Wibowo. 2017. Sebaran kondisi ekosistem hutan mangrove di kawasan Teluk Jailolo, Kabupaten Halmahera Barat, Provinsi Maluku Utara. J. Enggano, 2(2): 143- 
155.

https://doi.org/10.31186/jenggano.2.2 .143-155

Tajima, Y., J.P. Lapidez, J. Camelo, M. Saito, Y. Matsuba, T. Shimozono, D. Bautista, M. Turiano, \& E.Cruz. 2017. Post-disaster survey of storm surge and waves along the coast of Batanes, the Philippines, caused by super typhoon Meranti/Ferdie. $J$. Coastal Engineering, 59(1): 1-12. https://doi.org/10.1142/S0578563417 500097

Tao, H., M. Li, M. Wang, \& G. Lü. 2019. Genetic algorithm-based method for forest type classification using multitemporal NDVI from Landsat TM imagery. Annals of GIS, 25(1): 33-43. https://doi.org/10.1080/19475683.201 8.1552621

Udo, K., Y. Takeda, \& H. Tanaka. 2016. Coastal morphology change before and after 2011 off the pacific coast of Tohoku earthquake tsunami at Rikuzen-Takata Coast. J. Coastal Engineering, 58(4): 1-16.

https://doi.org/10.1142/S0578563416 400167

Verbyla, D. \& T.A. Kurkowski. 2019. NDVI-climate relationships in highlatitude mountains of Alaska and Yukon territory. J. Arctic, Antarctic, and Alpine Research, 51(1): 397-411. https://doi.org/10.1080/15230430.201 9.1650542

Wei, C., J. Chen, J. M. Chen, J.C. Yu, Ch. P. Cheng, Y.J. Lai, P.N. Chiang, C.Y. Hong, M.J. Tsai, \& Y.N. Wang. 2020. Evaluating relationships of standing stock, LAI and NDVI at a subtropical reforestation site in Southern Taiwan using field and satellite Data. J. of Forest Research, 25(4): 250-259. https://doi.org/10.1080/13416979.202 0.1783752
Wicaksono, P. \& M. Hafizt. 2013. Mapping seagrass from space: addressing the complexity of seagrass LAI mapping. European J. of Remote Sensing, 46(1): 18-39. https://doi.org/10.5721/EuJRS201346 02

Xu, Z., Y. Chen, X. Meng, F. Wang, \& Z. Zheng. 2016. Phytoplankton community diversity is influenced by environmental factors in the coastal East China sea. European J. of Phycology, 51(1): 107-118. https://doi.org/10.1080/09670262.201 5.1107138

Yotsumoto, Y. 2012. Ecotour providers in the Kyushu region: The characteristics of Japanese ecotourism and its relationship with global warming. J. Contemporary Japan, 24(2): 243-265. https://doi.org/10.1515/cj-2012-0011

Zhai, K., X. Wu, Y. Qin, \& P. Du. 2015. Comparison of surface water extraction performances of different classic water indices using OLI and TM imageries in different situations. J. Geo-Spatial Information Science, 18(1): 32-42. https://doi.org/10.1080/10095020.201 5.1017911

Zhu, J. W. \& X. D. Zeng. 2016. Influences of the interannual variability of vegetation LAI on surface temperature. J. Atmospheric and Oceanic Science Letters, 9(4): 292297. https://doi.org/10.1080/16742834.201 6.1189800

Submitted : 1 March 2021

Reviewed : 24 March 2021

Accepted : 12 June 2021 
